\title{
KEPRIBADIAN GANDA SEBAGAI PELACUR PERSPEKTIF PSIKOLOGI KOMUNIKASI
}

\author{
Oleh : Rusli
}

\begin{abstract}
Abstrak
Persoalan sosial dalam kehidupan masyarakat tidak terlepas dari berbagai kebutuhan bidup manusia yang semakin hari semakin sulit dirasakan, hal ini menimbulkan berbagai masalah terhadap perilaku seseorang dalam memenubi kebutuban hidupnya. Masalab sosial terbentuk oleh kombinasi faktor-faktor internal yang berasal dari dalam diri seseorang dan faktor-faktor eksternal yang berasal dari lingkungan sosial. Pelacuran salah penyakit masyarakat yang dianggap sebagai pekerjaan atau sering disebut dengan Pekerja Seks Komersial (PSK). Seorang pelacur yang mempunyai kepribadian ganda dalam kehidupannya yaitu sebagai pelacur dan juga sebagai seorang yang memiliki keyakinan terhadap agamanya, bal ini menimbulkan konflik dalam dirinya antara kebenaran dan kekufuran yang dilakukannya. Nilai-nilai atau norma-norma agama yang mengarabkean seseorang kepada kebenaran dan kepribadian yang sebenarnya sebagai manusia ideal. Bila dilihat dalam perspektif psikologi komunikasi, tepatnya dalam psikologi kognitif tidak terlepas dari psikologi sosial. Pengarub psikologi kognitif ini dalam psikologi sosial, terutama untuk meggambarkan perkembangan konsepsi sebagai manusia.
\end{abstract}

Kata Kunci : Kepribadian Ganda, Psikologi Komunikasi.

\section{A. Pendahuluan}

Peran ganda seorang pelacur merupakan perilaku yang diemban dalam menjalankan kehidupannya baik seorang pelacur maupun seorang yang mempunyai kenyakinan sebagai orang yang beragama, dalam kehidupannya, pelacur sebagai dampak dari masalah sosial yang pada akhirnya menjadi suatu penyakit sosial masyarakat yang merasuk kedalam jiwa seseorang yang ditimbulkan dari berbagai persoalan, baik dari pengalaman buruk, faktor ekonomi, faktor lingkungan, dan lain sebagainya dalam kehidupan mereka.

Masalah sosial terbentuk oleh kombinasi faktor internal yang berasal dalam diri seseorang dan faktor eksternal yang berasal dari lingkungan sosial. Sementara patologi sosial ialah suatu penyakit sosial yang ditimbulkan oleh masalah sosial. Salah satu penyakit sosial adalah pelacuran atau prostitusi, pada hakekatnya adalah perbuatan yang bertentangan dengan norma agama, moral, kesusilaan maupun hukum, serta membahayakan bagi penghidupan dan kehidupan masyarakat, bangsa dan negara. Kenyakinan seorang pelacur kepada agamanya merupakan kewajiban seorang manusia yang menyarahkan diri serta pengabdiannya kepada sang pencipta sautu hal yang mutlak. 
Peran seorang pelacur dan seorang yang beragama sungguh bertentangan dari kedua peran tersebut, di suatu sisi mengerjakan perbuatan yang melangar norma dan nilainilai kemanusiaan, di sisi lain harus mengakui kebenaran nilai-nilai dalam masyarakat yaitu sebagai layaknya prilaku manusia normal pada umumnya menjalankan ajaran agamanya sesuai dengan tuntunan Allah dan RasullNya. Untuk lebih jelas dalam pembahasan ini penulis mencoba menguraikan: Pengertian pelacuran atau prostitusi, faktor timbulnya pelacuran, pelacuran menurut pandangan Islam, dampak pelacuran, kepribadian ganda pelacur Perspektif Psikologi Komunikasi, prediksi dan solusi mengatasinya.

\section{B. Pembahasan}

\section{Pengertian Pelacuran atau Prostitusi}

Menurut bahasa, pelacur adalah orang perempuan yang melacur; sundal; wanita tunasusila; sedangkan pelacuran perihal menjual diri sebagai pelacur; penyundalan (Tim, 2008:791). Pelacuran dapat diartikan sebagai suatu pekerjaan yang bersifat menyerahkan diri kepada umum untuk melakukan perbuatan-perbuatan seksual dengan mendapat upah (Soekanto, 2007:328). Pelacuran atau prostitusi merupakan salah satu bentuk penyakit masyarakat yang harus dihentikan penyebarannya, tanpa mengabaikan usaha pencegahan dan perbaikan. Pelacuran berasal dari bahasa Latin pro-stituere atau pro-stauree, yang berarti membiarkan diri berbuat zina, melakukan persundalan, percabulan, dan pengendakan. Sedangkan prostitue adalah pelacur atau sundal. Di kenal pula dengan istilah W'TS atau wanita tunasusila (Kartono, 2007:207).

Tunasusila atau tidak susila itu diartikan sebagai kurang beradab karena keroyalan relasi seksualnya dalam bentuk penyerahan diri pada banyak lali-laki untuk pemuasan sesual dan mendapatkan imbalan jasa atau uang bagi pelayanannya. Tunisusila itu juga bisa diartikan sebagai salah tingkah, tidak susila atau gagal menyesuaikan diri terhadap normanorma susila. Maka pelacur itu adalah wanita yang tidak pantas kelakuannya dan bisa mendatangkan mala/celaka dan penyakit, baik kepada orang lain yang bergaul dengan dirinya, maupun kepada diri sendiri (Kartono, 2007:207).

Pelacur adalah profesi yang menjual jasa untuk memuaskan kebutuhan seksual pelanggan. Biasanya pelayanan ini dalam bentuk menyewakan tubuhnya. Dari kedua definisi ini dapat disimpulkan bahwa prostitusi merupakan perzinaan dengan menjual jasa 
untuk memuaskan kebutuhan seksual berupa menyewakan tubuh. Sehingga prostitusi bersifat negatif dan dapat digolongkan sebagai kejahatan terhadap masyarakat.

Wanita Tunasusila disebut juga dengan istilah pekerja seks komersial (PSK) adalah seseorang yang menjual jasanya untuk melakukan hubungan seksual untuk uang. Di Indonesia pelacur (pekerja seks komersial) sebagai pelaku pelacuran sering disebut sebagai sundal atau sundel. Ini menunjukkan bahwa prilaku perempuan sundal itu sangat begitu buruk hina dan menjadi musuh masyarakat, mereka kerap digunduli bila tertangkap aparat penegak ketertiban, mereka juga digusur karena dianggap melecehkan kesucian agama dan mereka juga diseret ke pengadilan karena melanggar hukum. Pekerjaan melacur atau nyundal sudah dikenal di masyarakat sejak berabad lampau ini terbukti dengan banyaknya catatan tercecer seputar mereka dari masa kemasa. Sundal selain meresahkan juga mematikan, karena merekalah yang ditengarai menyebarkan penyakit AIDS akibat perilaku sex bebas tanpa pengaman bernama kondom.

Pelacuran merupakan masalah sosial yang berpengaruh sangat besar terhadap perkembangan moral. Kondisi ini sangat mengkawatirkan terhadap masalah bagi keluarga dan generasi muda, serta akan semakin menjalarnya penyakit kelamin. Penyakit kelamin ini terasa semakin menjalar akhir-akhir ini karena semakin banyaknya korban penyakit HIV/AIDS yang belum ditemukan obatnya. Pelacuran berkembang karena dorongan tekanan-tekanan sosial, keputusasaan, kehilangan pekerjaan, pelarian bagi yang putus cinta, dan semakin banyaknya orang yang menggandrunginya. Hal ini ditandai oleh adanya fasilitas lokasi secara khusus, meski beralasan daripada berkeliaran di jalan-jalan, di stasiun kereta api, di sekitar kantor polisi, atau di tempat-tempat umum yang terlihat sepi. Pada masa sekarang angin pelacuran semakin bias dengan penyebutan nama dengan pekerja seks komersil (PSK) dibanding wanita tuna susila (WTS). Dari adanya nama ini, pelacur atau WTS yang terkesan suatu penyimpangan perilaku, berubah pada posisi yang lebih baik kalau tidak bisa dibilang lebih terhormat dengan sebutan PSK. Sebutan PSK memposisikan mereka sebagai bagian dari salah satu profesi dalam masyarakat. Bila nilai-nilai moral dan keterlanjuran itu semakin terpatri dalam jiwa para pelaku ditambah adanya anggapan bahwa pekerjaan PSK mudah dilakukan, tidak memerlukan keterampilan khusus, dan banyak mendatangkan uang dengan mudah, maka perkembangan pelacuran semakin sulit diberantas. Meski mereka ditangkap dan diberikan keterampilan suatu usaha, maka setelah menjalani hukuman, mereka akan kembali kepada kegiatan pelacuran. 


\section{Faktor Penyebab Timbulnya Pelacuran}

Menurut Soetarso, masalah sosial terbentuk oleh kombinasi faktor-faktor internal yang berasal dari dalam diri orang (ketidakmampuan, kecacatan, gangguang jiwa, dan sebagainya) dan faktor-faktor eksternal yang berasal dari lingkungan sosial (keluarga, sekolah, lingkungan tetangga, lingkungan kerja, dan sebagainya). Berat ringanya suatu masalah sosial yang dialami oleh penyandang kerapkali bergantung faktor-faktor penyebab yang dialami serta variabel-variabel di dalam dirinya, terutama persepsi, kebutuhan, nilai, kemampuan, harapan, pengalaman dan perasaannya. Dalam kaitan ini dikenal dengan adanya penyandang masalah ganda, baik individu maupun keluarga (Huraerah, 2011: 8).

Menurut Soekanto sebab-sebab terjadinya pelacuran haruslah dilihat pada faktorfaktor endogen dan eksogen. Di antara faktor-faktor endogen dapat disebutkan nafsu kelamin yang besar, sifat malas, dan keinginan yang besar untuk hidup mewah. Di antara faktor-faktor eksogen yang utama adalah faktor ekonomis, urbanidsasi yang tak teratur, keadaan perumahan yang tak memenuhi syarat, dan seterusnya. Sebab utama sebenarnya adalah konflik mental, situasi hidup yang tidak menguntungkan pada masa anak-anak, dan pola kepribadian yang kurang dewasa, ditambah dengan intelegensia yang rendah tarafnya (Soekanto, : 2007: 328).

Menurut Kartini Kartono, berlangsungnya perubahan-perubahan sosial yang serba cepat dan perkembangan yang tidak sama dalam kebudayaan, mengakibatkan ketidakmampuan banyak individu untuk menyusuaikan diri, mengakibatkan timbulnya disharmoni, konflik-konflik eksternal dan internal, juga diorganisasi dalam masyarakat dan dalam diri pribadi. Peristiwa-peristiwa tersebut di atas memudahkan individu menggunakan pola-pola reposi/reaksi yang inkonvensional atau menyimpang dari pola-pola umum yang berlaku. Dalam hal ini ada pola pelacuran, untuk mempertahankan hidup di tengah-tengah hiruk pikuk alam pembangunan, khususnya di Indonesia (Kartono, 2007: 242).

Dari beberapa pandangan di atas faktor timbulnya pelacuran tidak terlepas dari adanya keinginan dan dorongan manusia untuk menyalurkan kebutuhan seks, khususnya di luar ikatan perkawinan, serta nafsu kelamin yang besar mengakibatkan ketidakmampuan banyak individu untuk menyusuaikan diri, mengakibatkan timbulnya disharmoni. Faktor lain ialah keterbatasan ekonomi yang menjadi ketidak cukupan dalam memenuhi kebutuhan hidup baik sandang maupun pangan. 


\section{Pelacuran Menurut Pandangan Islam}

Menurut pandangan Islam pelacuran atau zina merupakan salah satu perbuatan dosa besar. Bagi pezina yang belum menikah, maka wajib didera 100 kali cambukan, dan boleh diasingkan selama satu tahun. Bagi pezina yang sudah menikah maka harus dirajam hingga mati. Seperti firman Allah dalam Al-Qur'an Surat An Nur ayat 2.

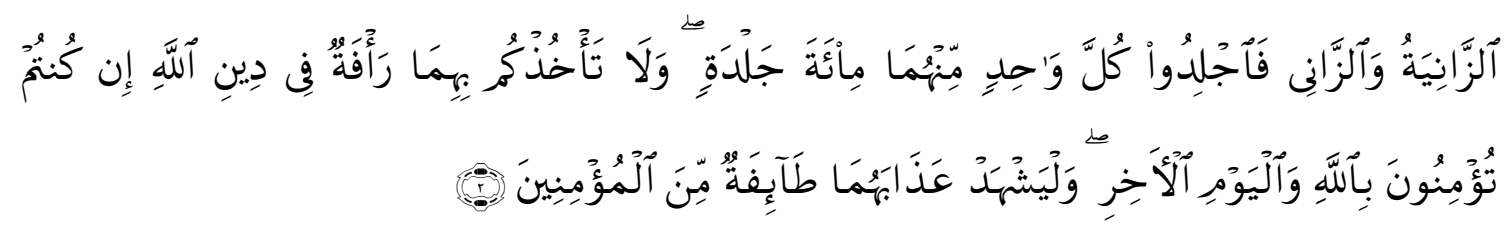

Artinya : perempuan yang berzina dan laki-laki yang berzina, Maka deralah tiap-tiap seorang dari keduanya seratus dali dera, dan janganlah belas kasiban kepada keduanya mencegah kamu untuk. (menjalankan) agama Allah, jika kamu beriman kepada Allah, dan hari akhirat, dan hendaklah (pelaksanaan) bukuman mereka disaksikan oleh sekumpulan orang-orang yang beriman. (QS. An Nur 24:2).

Di ayat yang lain Allah berfirman :

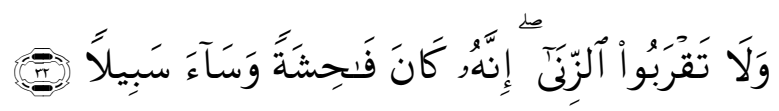

Artinya : dan janganlab kamu mendekati zina; Sesungguhnya zina itu adalah suatu perbuatan yang keji. dan suatu jalan yang buruk. (Q.S. Al-Israa' 17 : 32).

Rasulullah saw. bersabda dalam sebuah hadis yang di riwayatkan oleh Atthabrani dan Al-Hakim yaitu : "Apabila perzinaan dan riba telah melanda suatu negeri maka meraka (penghuninya) sudab menghalalkan atas mereka sendiri siksaan Allab". (HR. Atthabrani dan AlHakim) (Almath, 1991: 296).

Di hadis yang lain Rasulullah saw. bersabda. "Tercatat atas anak. Adam nasibnya dari perzinaan dan dia pasti mengalaminya. Kedua mata zinanya melihat, kedua telinga zinanya mendengar, lidah zinanya berbicara, tangan zinanya memaksa, (memengang dengan keras), kaki zinanya melangkah (berjalan) dan hatinya yang berhastrat dan berharap. Semua itu dibenarkan (direalisir) oleb kelamin atau digagalkanya”. (HR. Bukhari) (Almath, 1991: 297).

Di Indonesia sendiri pelacuran di kenakan hukuman seperti dalam pasal 296 KUHP yaitu "barang siapa yang pekerjaannya atau kebiasaannya, dengan sengaja mengadakan atau memudabkan perbuatan cabul dengan orang lain, dibukum dengan bukuman penjara selama-lamanya satu tabun empat bulan atau denda sebanyak-banyaknya seribu rupiab". dan pasal 506 KUHP, yaitu "barang siapa yang sebagai mucikari mengambil untung dari perbuatan cabul seorang perempuan, dibukum dengan bukuman kurungan selama-lamanya satu tabun". 
Untuk memberantas perzinahan, seharusnya negara tidak melokalisasi tempat pelacuran dan memungut pajak nya, akan tetapi menutupnya dan memberi hukuman bagi pezina, mucikari, germo dan organisasi yang menaunginya. Negara harus memberi sanksi dan menindak tegas para mucikari, germo dan orang yang termasuk memfasilitasi orang lain untuk berzina dengan sarana apapun dan dengan cara apapun, baik dengan dirinya sendiri maupun orang lain, tetap akan dikenakan sanksi. Sanksi bagi mereka menurut pandangan Islam adalah penjara 5 tahun dan dijilid. Jika orang tersebut suami atau mahramnya, maka sanksi diperberat menjadi 10 tahun.

Sedangkan jika germo, mucikari serta fasilitator perzinahan sudah meningkatkan aktifitasnya sampai mendirikan sebuah organisasi untuk mengayomi dan mengorganisir aktifitas perzinanahannya maka Negara harus membubarkan organisasi pelindung perzinahan tersebut dan menghukum mati para pendiri, ketua dan pengurus organisasinya

\section{Dampak Pelacuran}

Menurut Kartini Kartono ada beberapa dampak yang ditimbulkan oleh pelacuran atau prostitusi, antara lain: (Kartono, 2007: 249-251).

a. Menimbulkan dan menyebarluaskan penyakit kelamin dan kulit. Penyakit yang paling banyak terdapat ialah syphilis dan gonorrhoe (kencing nanah). Terutama akibat syphilis, dan apabila tidak mendapat pengobatan yang sempurna, bisa menimbulkan cacat jasmani, dan rohani pada diri sendiri dan anak keturunan. Antara lain ialah : 1) congenital syphilis (sipilis herediter/keturunan) yang menyerang bayi semasih dalam kandungan, sehingga terjadi abortus/keguguran atau bayi lahir mati. Jika bayi bisa lahir, biasanya kurang bobot, kurang darah, buta, tuli, kurang inteligensinya, defekt (rusak cacat) mental dan defekt jasmani lainnya. 2) syphilitic amentia, yang mengakibatkan cacat mental ringan, retardasi atau lemah ingatan dan imbisilitas. Sedang yang berat bisa mengakibatkan serangan epilepsi atau ayan, kelumpuhan sebagian dan kelumpuhan total, bisa jadi idiot psikotik, atau menurunkan anak-anak idiocy.

b. Merusak sendi-sendi kehidupan keluarga. Suami-suami yang tergoda oleh pelacur biasanya melupakan fungsinya sebagai kepala keluarga, sehingga keluarga menjadi berantakan.

c. Mendemoralisasi atau memberikan pengaruh demoralisasi kepada lingkungan khususnya anak-anak muda dan remaja pada masa puber dan adolesensi. 
d. Berkorelasi dengan kriminalitas dan kecanduan bahan-bahan narkotika (ganja, morfin, heroin, dan lain-lain).

e. Merusak sendi-sendi moral, susila, hukum, dan agama. Terutama sekali menggoyahkan norma perkawinan, sehingga menyimpang dari adat kebiasaan, norma hukum, dan agama, karena digantikan dengan pola pelacuran dan promiskuitas, yaitu digantikan dengan pola pemuasan kebutuhan seks dan kenikmatan seks yang awut-awutan, murah serta tidak bertanggung jawab. Bila sendi kehidupan keluarga yang sehat.

f. Adanya pengeksploitasian manusia oleh manusia lain. Pada umumnya wanita-wanita pelacur itu cuma menerima upah sebagian kecil saja dari pendapatan yang harus diterimanya, karena sebagai besar harus diberikan kepada germo, calo-calo, centengcenteng, pelindung, dan lain-lain. Dengan kata lain, ada sekelompok manusia benalu yang memeras darah dan keringat para pelacur ini.

g. Bisa menyebabkan terjadinya disfungsi seksual, misalnya : impotensi, anorgasme, nymfomania, satiriasis, ejakulasi prematur yaitu pembuangan sperma sebelum zakar melakukan penetrasi dalam vagina atau liang sanggama, dan lain-lain.

\section{Kepribadian Ganda Pelacur Perspektif Psikologi Komunikasi}

Menurut Freud, perilaku manusia merupakan hasil interaksi tiga sistem dalam kepribadian manusia $I d$, Ego, dan Superego. Id adalah bagian kepribadian yang menyimpan dorongan-dorongan biologis manusia pusat instink (hawa nafsu dalam kamus agama). Ada dua instink dominan : a) Libido - instink reproduktif yang menyediakan energi dasar untuk kegiatan-kegiatan manusia yang konstruktif; b) thanatos - intink destruktif dan agresif. Yang pertama disebut juga instink kehidupan (eros), yang dalam konsep Freud bukan hanya meliputi dorongan seksual, tetapi segala hal yang mendatangkan kenikmatan termasuk kasih ibu, pemujaan kepada tuhan, dan cinta diri (narcisism). Bila yang pertama adalah intink kehidupan, yang kedua merupakan instink kematian. Semua motif manusia adalah gabungan antara eros dan thanatos. Id bergerak berdasarkan prinsip kesenangan (pleasure prinsiple), ingin segera memenuhi kebutuhannya. Id. Bersifat egoistis, tidak bermoral dan tidak mau tahu dengan kenyataan. Id adalah tabiat hewani manusia (Rakhmat, 2007:19-20).

Tingkah laku immoril dari pelacur itu terutama sekali ditampilkan oleh simptomsimtom instabilitas jiwanya. Mobilitas profesionalnya bisa disamakan dengan hasratpengembaraanya yang psikopatik sifatnya. Kengganannya bekerja itu identik dengan 
kemalasan yang abnormal, ketidakacuhan dan "ndableg" tanpa perasaan susila pada dirinya, bisa disamakan dengan gejala schizofrenia (Kartono, 2007: 261).

Kepribadian seorang pelacur muncul dari sikap dan tingkah laku yang mereka tampilkan dalam kehidupan sehari-hari. Pada masa-masa awal wanita yang terjun ke dunia pelacuran, mereka berprilaku sadar dan merasa malu terhadap pekerjaan yang imoril itu. Perasaan yang demikian terdapat pada diri gadis-gadis yang masih baru, belum lama melakukan pekerjaan pelacuran, yaitu dengan pengalaman-pengalaman inisiasi prostitusi. Akan tetapi, sekali mereka sudah terjun dalam profesi prostitusi, kemudian menjadi trampil dalam teknik-teknik seksual dan merasakan senangnya memiliki uang yang banyak dan barang-barang mewah yang mereka peroleh dari hasil pekarjaan tersebut, maka berlangsunglah proses disosialisasi dan rasionalisasi yang mengalahkan semua pertimbangan rasional dan larangan hati nurani serta menundukkan segenap pertentangan/konflik batin. Pekerjaan melacurkan diri itu pada akhirnya menjadi pola kebiasaan, tanpa perasaan, tanpa afeksi, bahkan hampir-hampir tidak disadari lagi wanita yang bersangkutan secara total sudah menyukai peklerjaan tersebut.

Konflik-konflik dan kecemasan-kecemasan yang banyak diderita oleh para pelacur itu pada umumnya berkisar pada relasi cinta kasih dan tidak banyak berkaitan dengan masalah-masalah moral dalam kehidupannya. Artinya, semakin lama dia mencari unsur cinta kasih dan semakin lama profesinya, dan semakin jauh dan tidak ditemukannya cinta mesra itu. Seringkali hatinya di dera oleh kekosongan dan kesunyian, walaupun setiap hari dia berdekapan dengan macam-macam pria. Kehampaan cinta itulah sering menjadi sebab dari ketidakstabilan mental, kepedihan hati dan kecemasan-kecemasannya (Kartono, 2007: 262).

Walaupun $I d$ mampu mampu melahirkan keinginan, ia tidak mampu memuaskan keinginannya. Subsistem yang kedua - Ego - berfungsi menjembatani tuntutan $I d$ dengan realitas di dunia luar. Ego adalah mediator antara hastrat-hastrat hewani dengan tuntutan rasional dan realistik. Ego-lah yang menyebabkan manusia mampu menundukkan hasrat hewaninya dan hidup sebagai wujud yang rasional (pada pribadi yang normal) (Rakhmat, 2007:20).

Unsur moral dalam pertimbangan terakhir disebut Freud sebagai Superego. Superego adalah polisi kepribadian, mewakili yang ideal. Superego adalah hati nurani (conscience) yang merupakan internalisasi dari norma-norma sosial dan kultur masyarakatnya. Ia memaksa Ego untuk menekan hastrat-hastrat yang tak berlainan ke alam bawah sadar. Baik $I d$ maupun 
superego berada dalam bawah sadar manusia. Ego berada di tengah, antara memenuhi desakan $I d$ dan peraturan superego. Untuk mengatasi ketegangan, ia dapat menyerah pada tuntutan $I d$, tetapi di hukum superego dengan perasaan bersalah. Untuk menghindari keterangan, konflik, atau frustasi ego secara tak sadar lalu menggunakan mekanisme pertahanan ego, dengan mendistorsi realitas. Secara singkat dalam psikoanalisis perilaku manusia merupakan interaksi antara komponen biologis (Id), komponen psikologis (ego), dan komponen sosial (superego); atau unsur animal, rasional, dan moral (hewani, akal, nilai) ((Rakhmat, 2007:20).

Bila dilihat dalam perspektif psikologi komunikasi, tepatnya dalam psikologi kognitif tidak terlepas dari psikologi sosial. Secara sederhana akan melihat pengaruh psikologi kognitif ini dalam psikologi sosial, terutama untuk meggambarkan perkembangan konsepsi manusia.

Sejak pertengahan tahun 1950-an berkembang penelitian mengenai perubahan sikap dengan kerangka teoritis manusia sebagai pencari konsistensi kognitif (The Person as Consistency Seeker). Di sini, manusia dipandang sebagai makhluk yang selalu berusaha menjaga keajegan dalam sistem kepercayaan, dan di antara sistem kepercayaan dengan perilaku. Contoh yang paling jelas adalah teori disonansi kognitif dari leon Festiger. Disonansi artinya ketidakcocokan antara dua kognisi ("pengetahuan"). Dalam keadaan disonan orang berusaha menguragi disonansi dengan berbagai cara. Disonansi membuat orang resah (Rakhmat, 2007:29).

Sebagai contoh adalah; Kognisi "saya tahu saya senang melacur", disonan dengan "saya tahu melacur melanggar norma susila dan agama bahkan menimbulkan banyak penyakit”. Dihadapkan dalam situasi disonan seperti itu, saya akan : a) mengubah perilaku, behenti sebagai seorang pelacur, 'Saya melacur untuk kebutuhan ekonomi”, b) mengubah kognisi tentang lingkungan, misalnya hanya pelacur tetap yang menimbulkan penyakit, c) memperkuat salah satu kognisi yang disonan, “ah, kawan-kawan saya pun banyak yang menjadi pelacur", atau d) mengurangi disonansi dengan memutuskan bahwa salah satu kognisi tidak penting. "tidak jadi soal menjadi pelacur akan menimbulkan penyakit. Toh saya ingin hidup cepat dan nantinya akan mati juga".

Dalam teori komunikasi, teori disonansi menyatakan orang akan mencari informasi yang mengurangi disonansi, dan menghindari informasi yang manambah disonansi. Bila anda terpaksa juga dikenai informasi yang disonan dengan kenyakinan anda, anda akan 
menolak informasi itu, meragukan sumbernya, mencari informasi yang konsonan, atau mengubah sikap sama sekali (Rakhmat, 2007:29).

Pada umumnya pekerjaan melacurkan diri oleh wanita-wanita yang lemah ingatannya, abnormal jiwanya, psikopatik ataupun yang mengalami demoralisasi berat. Wanita-wanita yang seperti itulah yang banyak terdapat dikalangan pelacur. Secara sadar tidak mungkin wanita yang normal mau merendahkan dirinya seperti pekerjaan pelacuran. Pekerjaan pelacuran merupakan bentuk penyimpangan sosio-psikologis, yang disebabkan oleh faktor-faktor sosial dan faktor psikologis.

Dalam proses komunikasi yang berkaitan dengan psikologi terdapat pengaruh di dalam diri seorang pelacur, yang bahwa pekerjaan yang mereka lakoni pada dirinya bertentangan dengan batiniahnya, apalagi kalau dilihat dari segi keyakinannya seperti, seorang muslim dia mengetahui pekerjaan yang mereka lakukan tersebut bertantangan dengan syariat, namun di sisi lain mereka menganggap pekerjaan pelacuran untuk menutupi kebutuhan hidupnya secara ekonomi (mempertahankan hidup) dan pekerjaan tersebut juga bisa memuaskan hawa nafsu seksualnya. Seorang pelacur yang mempunyai kepribadian ganda seperti ini, sering terjadinya konflik dalam diri antara kebenaran dan kekufuran yang dilakukannya.

Seorang manusia yang mempunyai akal yang sehat tidak bisa keluar dari kebenaran seperti yang digambarkan oleh Freud nilai-nilai atau norma-norma agama yang mengarahkan seseorang kepada kebenaran dan kepribadian yang sebenarnya manusia ideal. Dalam proses komunikasi terdapat dalam diri sendiri yang disebut dengan komunikasi intrapesonal yaitu komunikasi dengan diri sendiri dan juga kepada sang khaliq.

Menurut Kholil dalam ilmu komunikasi dikenal dengan istilah komunikasi intrapersonal, maksudnya ialah komunikasi yang dilakukan oleh seseorang dengan dirinya sendiri termasuk di dalamnya introspeksi dirinya. Manakala komunikasi transendental ialah komunikasi yang dilakukan oleh manusia dengan Tuhan yang bersifat gaib, misalnya ketika melaksanakan shalat (Kholil, 2007:114).

Merenung merupakan suatu langkah tepat yang dilakukan dengan mencermati dan mempertanyakan tentang persoalan hidup dan kehidupan secara tulus dan jernih. Perenungan akan dapat mencapai suatu keadaan yang positif bila memenuhi dua syarat : a) beribadah dengan baik dan berfikir, b) banyak mengingat peristiwa yang sedih dan menakutkan, puncaknya adalah mengingat siksa yang keras (Ma'arif, 2010:93). 
Dalam proses komunikasi inilah seorang pelacur mempunyai instink dalam diri, di satu sisi dia melakukan dosa atau perbuatan yang menyimpang dari norma-norma agama, di sisi lain tidak bisa menolak kebenaran yang terdapat pada dirinya, seperti mengamalkan agamanya dengan melakukan taubat, dan menjadi manusia yang normal seperti layaknya manusia yang beragama dan menjalankan ibadah sesuai dengan tuntunan Allah dan RasulNya.

Pada umumnya pada usia 30 tahun para pelacur banyak timbul konflik pada dirinya para pelacur. Bila pekerjaan memperdangankan seks itu dilanjutkan, secara fisik sudah tidak kuat lagi, kecantikan sudah mulai memudar, penghasilan pun sudah mulai menurun. Jasmani dan rohani sudah mulai lelah, mutlak mereka harus menghentikan pekerjaan tersebut. Jiwa mereka sudah mulai dihantui dengan banyangan akan terjadi kemiskinan, kelaparan, dan penderitaan. Terjadilah konflik-konflik batin yang serius sehingga tidak jarang menjelma menjadi gangguan mental.

Oleh sebab itu perilaku yang ditimbulkan oleh para pelacur dapat mempengaruhi psikologi mereka yang bersifat kepribadian ganda yang dibentuk oleh pola pikir yang tidak sehat. Konflik batin yang terjadi antara perbuatan sebagai pelacur yang dipengaruhi oleh faktor Id (nafsu hewani), dan seorang manusia normal yang dipengaruhi oleh faktor Ego (akal sehat), selanjutnya timbul rasa bersalah ingin keluar dari perbuatan tercela tersebut. Prilaku seperti ini lambat laun berdampak kepada gangguan mental, kegoncangan dalam dirinya, seperti pelanggaran nilai yang disebut dengan Superego (nilai-nilai) kemasyarakatan.

\section{Prediksi}

Pelacuran merupakan salah satu penyakit masyarakat yang meresahkan yang harus dihentikan oleh pemerintah, jika praktek pelacuran yang terjadi selama ini di berbagai kota tidak ditangani dengan baik oleh pemerintah, maka penulis memprediksi akan terjadi berbagai persoalan lain pada masyarakat luas, akan menggangu tatanan masyarakat dan berdampak nergatif seperti, tertularnya penyakit seksual yang berasal dari pelacur kepada masyarakat secara luas akibat melakukan hubungan seksual dengan pelacur, seperti penyakit syphilis dan gonorrhoe (kencing nanah), HIV/AIDS yang belum ditemukan obatnya setiap tahun makin bertambah, dan tindakan kriminalitas lainnya yang mengakibatkan menggangu ketentaraman, dan kenyamanan masyarakat secara umum. 


\section{Solusi Mengatasi Pelacuran}

Dalam menanggulangi masalah prostitusi ini sangatlah sukar dan harus melalui proses dan waktu yang panjang, dan memerlukan pembiayaan yang besar. Usaha untuk mengatasi masalah prostitusi ini dapat dibagi menjadi dua, yaitu :

a. Usaha yang bersifat preventif

Usaha yang bersifat preventif diwujudkan dalam kegiatan-kegiatan untuk mencegah terjadinya pelacuran. Usaha ini antara lain berupa :

1) penyempurnaan perundang-undangan mengenai larangan atau pengaturan penyelenggaraan pelacuran.

2) pemberian pendidikan keagamaan dan kerohanian, untuk memperkuat keimanan terhadap nilai-nilai religius dan norma kesusilaan

3) memperluas lapangan kerja bagi kaum wanita, diseseuaikan dengan kodrat dan bakatnya, serta mendapatkan upah/gaji yang cukup untuk memenuhi kebutuhan hidup setiap harinya.

4) penyelenggaraan pendidikan seks dan pemahaman nilai perkawinan dalam kehidupan keluarga

5) penyitaan terhadap buku-buku dan majalah-majalah cabul, gambar-gambar porno, film-film biru dan sarana-sarana lain yang merangsang nafsu seks.

6) meningkatkan kesejahteraan rakyat pada umumnya

b. Tindakan yang bersifat represif dan kuratif

Usaha yang represif dan kuratif dimaksudkan sebagai kegiatan untuk menekan dan usaha menyembuhkan para wanita dari ketunasusilaannya untuk kemudian membawa mereka ke jalan yang benar. Usaha tersebut antara lain berupa :

1) melalui lokalisasi, dengan lokalisasi masyarakat dapat melakukan pengawasan atau kontrol yang ketat. Karena lokalisasi sendiri pada umumnya di daerah terpencil yang jauh dari keramaian.

2) untuk mengurangi pelacuran, diusahakan melalui aktivitas rehabilitasi dan resosialisasi, agar mereka bisa dikembalikan sebagai warga masyarakat yang susila. Rehabilitasi dan resosialisasi ini dilakukan melalui: pendidikan moral dan agama, latihan-latihan kerja dan pendidikan keterampilan agara mereka bersifat kreatif dan produktif. 
3) penyempunaan tempat-tempat penampungan bagi para wanita tunasusila yang terkena razia; disertai pembinaan yang sesuai dengan bakat dan minat masingmasing.

4) menyediakan lapangan kerja baru bagi mereka yang bersedia meninggalkan profesi pelacuran dan mau memulai hidup susila

\section{Penutup}

Pelacuran merupakan pekerjaan yang menyimpang dari norma dan nilai-nilai agama, dan merusak tatanan masyarakat secara luas. Perilaku seorang pelacur di dorong oleh keinginan dalam dirinya dengan sifat $I d$ (nafsu hewani). Pelacur juga merupakan profesi yang menjual jasanya untuk memuaskan kebutuhan seksual pelanggan. Biasanya pelayanan ini dalam bentuk menyewakan tubuhnya. Akibat yang ditimbulkan oleh pelacuran dapat berdampak pada terjangkitnya berbagai macam penyakit seperti HIV/AIDS yang mematikan dan bisa menularkan kepada orang lain yang berhubungan seksual dengannya.

Kepribadian ganda yang terdapat pada diri seorang pelacur mengakibatkan konflik batiniyah yang hebat mengakibatkan ganguan mental akibat dari perilaku yang dilakukannya baik sebagai pelacur (perilaku yang menyimpang) juga sebagai manusia normal secara ideal. Kedua kepribadian inilah yang mempengaruhi psikologis seorang pelacur sehingga terjadi kegoncangan dalam dirinya, seperti rasa bersalah disebut dengan Superego sesuai dengan kenyakinan dan keimanan seorang pelacur. 


\section{DAFTAR PUSTAKA}

Almath, Muhammad Faiz, 1100 Hadits Terpilih Sinar Ajaran Mubammad, terj. A. Aziz Salim Basyarahil, Jakarta: Gema Insani, 1991.

Huraerah, Abu, Pengorganisasian dan Pengambangan Masyarakat, model \& Strategi Pembangunan Berbasis Kerakyatan, Bandung: Humaniora, 2011.

Kartono, Kartini, Patologi Sosial, Jilid I, Jakarta: Raja Grafindo Persada, 2007.

Kholil, Syuku, Komunikasi Islami, Bandung : Citapustaka Media, 2007.

Ma'arif, Bambang Sauful, Komunikasi Dakwah paradigma untuk Aksi, Bandung : Simbiosa Rekatama Media, 2010.

Rakhmat, Jalaluddin, Psikologi Komunikasi, Cet-25, Bandung : Remaja Rosdakarya, 2007.

Soekanto, Soerjono, Sosiologi Suatu Pengantar, Jakarta : RajaGrafindo Persada, 2007.

Tim Penyusun Kamus Pusat Bahasa, Kamus Bahasa Indonesia, Jakarta: Pusat Bahasa, 2008. 